Network Analysis for Planning and Scheduling 


\section{Studies in Management}

General Editor: SAMUEL EILON, D.SC (ENG), PH.D, D.I.C, M.I.MECH.E, M.I.PROD.E. Professor of Industrial and Management Engineering, Imperial College, London

NETWORK ANALYSIS

for Planning and Scheduling

EXERCISES IN INDUSTRIAL MANAGEMENT

$A$ Series of Case Studies

APPLIED QUEUEING THEORY

WORK MEASUREMENT

Some Research Studies

MATHEMATICAL PROGRAMMING

for Business and Industry
A. Battersby

S. Eilon, R. I. Hall, and J. R. King

A. M. Lee

N. A. Dudley

K. B. Haley 


\section{Network Analysis}

\section{for Planning and Scheduling}

Albert Battersby, M.A, B.Sc, F.R.I.C.

Senior Research Fellow in Management Studies,

Balliol College, Oxford

\section{Third Edition}




$$
\begin{array}{r}
\text { ISBN 978-1-349-00596-3 } \begin{array}{r}
\text { ISBN } 978-1-349-00594-9 \text { (eBook) } \\
\text { DOI } 10.1007 / 978-1-349-00594-9
\end{array} \\
\text { C A. BATTERSBY } 1970
\end{array}
$$

Softcover reprint of the hardcover 3rd edition 1970 978-0-333-08903-3

First published 1964 Reprinted 1965

Second Edition 1967

Third Edition 1970

Published by MACMILLAN AND CO LIMITED

Little Essex Street London w $\mathrm{C}_{2}$ and also at Bombay Calcutta and Madras Macmillan South Africa (Publishers) Pty Ltd Johannesburg The Macmillan Company of Australia Pty Ltd Melbourne The Macmillan Company of Canada Ltd Toronto Gill and Macmillan Ltd Dublin 


\section{Preface to the Third Edition}

In the preface to the second edition, I commented on the rapid growth of network analysis in technique and application. Since then, growth has continued to such an extent that project networks are now an accepted part of modern management. In technique, the development since the fifties has been so great as to pose a problem to both the author and the publisher in compiling a basic textbook such as this; the pressure to include new material is opposed by the need to keep the book within a reasonable compass and to an acceptable price. The elementary principles of network analysis still stand firm, however, and the latest developments are, on the whole, forseeable improvements of the work of pioneers in the subject. Where new material has been added, it therefore refers in the main to basic principles.

One of the great features of the original PERT (now PERT/Time) System lay in its assessment of probabilities, but well informed teams and individuals have confirmed my own experience that probability estimates are not at present in serious practical use on either side of the Atlantic. That is not to say that they never will be, so I have not eliminated such matter entirely but merely relegated it, heavily summarized, to Appendix I. In doing so, I express the hope that some researcher will finally crack the difficult nut of estimating and combining probabilities more rigorously than at present, and that the level of numeracy among managers will rise to the point at which they not merely accept probabilistic statements, but demand them.

The long-awaited British Standard Glossary is now with us and the new standardized symbols are entirely consistent with those originally used by me in earlier editions and the differences of nomenclature or usage are few and far between. There is one exception: when this book was written the technical vocabulary was still in the formative stage and the word job was used rather than the alternative, activity. The British Standards Institution prefers the latter term and, while I have not made the extensive alterations needed to ensure conformity, I strongly recommend a uniform usage based on B.S. 4335 .

To some extent, the progress of this book through successive editions reflects the spread of Network Analysis on the European side 
of the Atlantic. When it first appeared in 1964 this book, together with that by Lockyer, was a pioneer book in the subject in Britain: it then had a twelve-page chapter on 'Practical Applications'. In the second edition in 1967 , this chapter was still about the same length, but in that year there burst upon the European scene a Conference on Applications of Critical Path Techniques, organized by the NATO Scientific Affairs Committee and richly subscribed to by delegates from all over Europe. The proceedings of this symposium have been collected into a volume by another pioneer of networks in the United Kingdom, Jim Brennan, and I have therefore omitted my own chapter in this edition as it now looks too brief a treatment.

Much of the advice given in later chapters of the first two editions was about good management in general and has been greatly condensed with a view to making the whole book more specific to Network Analysis itself.

A.B. 


\section{Acknowledgements}

Much of the material included here has been gathered informally from my professional colleagues both in industry and the academic world, and from the many managers who have attended and contributed to courses at Cranfield. Prominent amongst them are Mr. T. Russell, Dr. J. A. Carruthers, Mr. A. G. Simms, Prof. B. Roy, Mr. E. Buesnel and members of the Critical Path Analysis Study Group of the Operational Research Society.

A book of this kind calls for a lot of supporting work, which has been done in the most friendly and efficient way by:

Mr. S. R. Deards of the Department of Electrical Engineering at Cranfield (technical help in preparing Chapter I2).

Dr. S. Kirkby and Mr. S. Ingham of the Department of Mathematics at Cranfield (electronic computing for Case Study A).

Mr. I. G. McNaught-Davis, Mr. M. Nichols and Mr. C. Kehela of De la Rue Bull Machines Ltd. (electronic computing for Case Study B).

Mr. S. J. Johnson, Mrs. Myra Ellis and Miss Brenda Clark (the drawings: one has only to riffle the pages to see how big their contribution has been).

Many companies, large and small, and public bodies have released information about their work; they include :

A/B Atomenergi, Sweden

Aerospace Corporation, U.S.A.

Bristol Aircraft Co. Ltd.

British Oxygen Co. Ltd.

British Petroleum Co. Ltd.

British Rail

C.E.I.R. (U.K.) Ltd.

Central Electricity Generating Board

Cie des Machines Bull, France

Constructors John Brown Ltd.

De la Rue Bull Machines Ltd.

Department of Defense and National Aeronautics and Space Agency, U.S.A.

English Electric Leo Marconi Ltd. 
Esso Petroleum Co. Ltd.

Fison's Fertilizers Ltd.

Flowers' Breweries Ltd.

Formica Ltd.

Gallahers Ltd.

Henry Wilson and Co. Ltd.

Imperial Chemical Industries Ltd.

International Computers and Tabulators Ltd.

Ministry of Defence

Ministry of Public Building and Works

Modulex Ltd.

National Coal Board

S.E.M.A., France

Selection Trust Ltd.

Steel Company of Wales Ltd.

Texas Instruments Itd.

U.K. Atomic Energy Authority

Unilever Ltd.

Xerox Research and Engineering Center, U.S.A.

I thank also the editor of Operations Research for permission to reproduce Fig. 7.4, McGraw-Hill Limited for the extracts from Science, Technology and Management, and the U.S. Department of Defense for the illustrations from the PERT/COST Guide (Figs. 13.7, I3.8 and A5.3). The book-publishing example in Chapter ro has been rewritten from two articles of mine originally published in The Accountant, with the permission of the Editor.

It is also a pleasure to acknowledge here my great debt to the many correspondents who have offered suggestions and constructive criticisms, often in great detail and who have pointed out occasional errors in the earlier versions. And my wife has, as ever, sustained me through the trials of revision. 


\section{Contents}

Preface to the Third Edition $\mathbf{v}$

Acknowledgements vii

I Introduction I

2 Arrow Diagrams-I 8

3 Critical Paths 27

4 Arrow Diagrams-II 49

5 Bar Charts, Time Scales and Matrix Equivalents 79

6 The Method of Potentials 9I

7 Computers 104

8 Resource Allocation-The General Problem II5

9 Variable Costs and Durations I28

ro Analogue and Analytical Methods I43

II Heuristic Methods I66

I2 Capital, Materials and Storage Costs I84

I3 Monitoring, Control and Project Organization 193

I4 Installing Network Analysis 2 I2

Case Study A : Liquid Oxygen Tanker 224

Case Study B : Launching a New Product 242

Case Study C: Prevention and Detection of Crime 258

APPENDICES

I The PERT Statistics 26I

2 Standard Symbols 270

3 Types of Float 272

4 Probabilistic Networks 276

5 Estimating Durations and Costs 282

6 A Note on the Use of Modulex 287

Bibliography $\quad 289$

Solutions to Exercises 295

Index $\quad 325$ 